in support of his own proposal for a presidential commission.

At the NIH there is considerable concern about such proposals. Many fear the implication that it might remove from the institutes responsibility for deciding how basic research funds should be allocated. In terms strongly reminiscent of the debate in Britain that followed the proposals made by Lord Rothschild for reorganising medical research in the early 1970 s, they argue that planning is only effective when it is done by those with responsibility for carrying out the resultant decisions.

Dr Fredrickson's reluctance to see the $\mathrm{NIH}$ lose its grip on setting scientific priorities was endorsed by several advisory committee members. "In today's world it is often desirable to have a document available that you can refer to as your plan. But the greatest value of such a document is in its preparation - often the plan itself is best forgotten once it has been conceived" said Mr Benno C Schmidt, previously chairman of the President's cancer commission.

Other speakers recommended that if there were to be outside advice provided to government policy-makers, it should focus on management issues, rather than on the disaggregation of scientific priorities. "In five years as a member of the Defense
Science Board, I can remember only having discussed a scientific issue once. In the vast majority of cases we were involved with ways of helping the Department of Defense manage its resources better," said Dr Ivan Bennett, Provost and Dean of the New York University Medical Center.

Yet the issue of public participation is unlikely to be resolved that easily. One of the most controversial sections of the bill proposed by Senator Kennedy, due to be voted on by the Human Resources Committee in the next few weeks, is public participation in the peer review process, an idea anathema to most working scientists.

Mr Califano has previously expresed DHEW's strong opposition to the bill. Yet among the principles on which he has said health research should be established, it is stated that "to assure that HEW health research is responsive to public concerns, the public must participate in the setting of research policies and priorities".

So far, public participation has been interpreted largely as public comment, rather than significant involvement in decision-making.

"The process of public participation has been highly successful numerically, but not so effective in terms of give and take," said Dr Omenn. Despite the amount of material, there had not been much cross- cutting between people with a stake in the current system, and those with other ideas.

There will be a further opportunity for public debate soon when DHEW publishes a set of possible research initiatives for 1980 to 1984 . These have been prepared by a steering committee under Dr Fredrickson as an attempt to convert Mr Califano's "principles" into budget language. And they are expected to include "trans-NIH" programmes in subjects such as smoking and nutrition, as well as the suggested stabilisation of research project grants currently being pushed by OSTP.

The progress of next year's budget request through Congress will indicate how well these proposals, and the philosophy behind them, fare in the world of realpolitik. Dr Omenn reminded committee members that there might soon be a change in command in the Senate apropriations subcommittee responsible for medical research and that among potential candidates was Mr William Proxmire, no great friend of the research community.

"The numbers that we are proposing can be argued about", he said. But a stabilising strategy was important because it was "the type of process that those people who may dominate the appropriations committees for the next few years will be able to agree on".

\title{
Research on foot and mouth virus approved
}

In the first major decision on potentially hazardous experiments requiring special permission under federal safety guidelines, the recombinant DNA advisory committee of the US National Institutes of Health has given its approval in principle for experiments to be carried out on foot and mouth virus. Research workers hope that the research will eventually lead to the production of a new vaccine against the disease, a major threat to cattle in many parts of the world, and provide important information about antigenicity mechanisms.

The advisory committee last week recommended to the Director of NIH, Dr Donald Fredrickson, that he approve an application for such experiments that have been made jointly by scientists at the Plum Island Animal Disease Centre of the US Department of Agriculture - the only place in the US currently allowed to cultivate and study foot and mouth disease (FMD) virus - and the San Francisco firm, Genentech.

However before giving the experiments detailed approval, the committee has appointed a subcommittee to study the infectivity of the virus's genome and it is insisting that when genetic material from the virus is studied or transported, it should be in lengths short enough to ensure that there is virtually no danger of infection.

Under the NIH guidelines for recombinant DNA experiments, foot and mouth disease virus belongs to the set of pathogenic organisms on which experiments are prohibited without the specific approval of the Director of NIH.

The research proposal is aimed at identifying that part of the genetic material which codes for a protein attached to the virus surface which, if produced and administered in sufficient quantities,

\section{Carter sacks nuclear regulation chief}

Following consideration of the report of the Kemeny commission on last March's accident at the Three Mile Island nuclear plant, President Carter announced last week that he was replacing Mr Joseph Hendrie as chairman of the Nuclear Regulatory Commission.

However the President said that the accident had not changed his views about the need for nuclear power. "We cannot shut the door on nuclear energy", he said. Recent events in Iran had shown the "clear, stark dangers" of excessive dependence on imported oil.

President Carter said that he agreed fully with the "spirit and intent" of the Kemeny commission's recommendations. However, he urged that the NRC should complete its current internal review during which no new licenses or construction permits are being issued - "as quickly as possible," and in any event "no later than six months from today". would make an effective vaccine. Current vaccines are made from the whole virus, and the production techniques necessary to produce the 800 million doses of the vaccine used annually throughout the world are thought to be partly responsible for some of the outbreaks of the disease.

Under the research proposal submitted to NIH, research workers on Plum Island will produce double-stranded DNA from the FMD virions. Plasmids containing subgenomic fragments of the DNA will be prepared using the disabled $E$. coli $\mathrm{K} 12$ strain of bacteria and, after suitable testing against infectivity, will be transferred to Genentech in San Francisco.

Here the fragments will be characterised to identify that part of the genome corresponding to the desired protein. Once this has been achieved the protein can be expressed in $E$. coli, and it will then be tested for antigenic and immunogenic potency on animals at Plum Island.

At its meeting last week, the advisory committee agreed that it was important that the experiments should be carried out for both economic and scientific reasons. Its main concern was to ensure that the genome was fragmented so that infection was virtually guaranteed to be impossible.

One way to do this, according to Dr Howard Bachrach, the principal investigator on Plum Island, was to divide the genome into two segments, the longer one of which research workers at Pirbright in England had shown to be non-infective. 